\title{
THE EFFECTIVENESS OF PEER TUTORING IN TEACHING SPEAKING
}

\author{
MukhtarulAnam ${ }^{1)}$, Moh. Nurman ${ }^{2)}$ \\ ${ }^{1,2}$ Faculty of Teacher Training and Education ,Lamongan Islamic University, \\ Indonesia

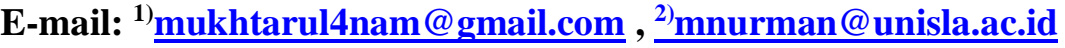

Submitted: 08-10-2020

Accepted: 29-11-2020

DOI: https://doi.org/10.22202/tus.2020.v6i1.4388

\begin{abstract}
Learning speaking is not easy for some students. This research is to know the different students' mean score by using peer tutoring and teacher tutoring in learning speaking. Experimental research is used at this research. The subjects of the research are VIII grade students of junior high school Sunan Santri Babat Lamongan. The sample in the research is 40 students providing 20 students of VIII B as the experimental group and 20 students of VIII A as the control group. The research instruments consist of pre- test, and post-test. In the research findings, the students who studied using peer tutoring has higher score than teacher tutoring in speaking. So, It is concluded that the use of peer tutoring is more effective for learning speaking than teacher tutoring. The researcher gives suggestions that peer tutoring is effective in teaching speaking because students can improve their ability and share with the groups. For the next researcher, it is suggested to carry out a research in the same study but in other places and subjects of the study.
\end{abstract}

\section{Keywords: Peer Tutoring, Speaking.}

\section{INTRODUCTION}

Speaking English is the difficult thing for people in Indonesia, because it is never used in daily communication. There are a lot of languages in this world. Almost every region has its own language. One of the famous languages is English. Many countries in this world use English. It is used to communicate. In addition, English becomes important because it has a crucial part in a lot of life aspects, such as economics, education, cultures, socials and etc.

Learning speaking is not easy for some students. For Indonesian students, English is applied in every levels of school, since elementary students to university students, but some students get difficult to speak English well. Because of many factors such as; English is not used for daily communication, between the speaking and pronunciation are different and etc. in studying English, the students have to understand 4 skills, those are listening, speaking, reading, and speaking. Speaking is one of competent that must be mastered by the students. Many 
students of junior high school get difficult to practice it. The students get difficult how to pronounce. In Junior high school, speaking is one of four skills avoided by most students. They think that speaking is the difficult lesson. The teacher must be creative to teach speaking skill to get more interesting. Meanwhile, in terms of process results learning is said to be successful when there is a positive change in behavior. Learning activities have components that support each other, those are; goals learning, students, teachers, learning methods, learning media, assessment and learning situations. The components must be manageable so that the learning process can run well.

Speaking skill is an activity to produce utterances in speaking, Brown (2015). The activity two or more persons, in which the persons are both speakers and listeners, must react to what they hear and make them contribution at high speed, so that each person has an intention or a set of intention that he wants. The researcher can conclude that skill of language is important to be mastered. But in fact, some students are very passive on speaking activity when they are asked to talk, give opinion, or response, they seem not to have any interest and be very afraid. In short, the speaker's cognitive network contains the motivating force behind the thought, content of speech, and knowledge system by means of which thought are converted into speech. All except the overt oral message itself are internal processes. In learning to speak, the learners must notice some aspects, which comprise pronunciation, fluency, intonation, etc. All of those aspects are not easy to learn especially for second language learners such as Indonesian students. Because of that there should be some efforts to enable them to master English language well especially the speaking skill.

Peer tutoring is one of methods provides the development on teaching speaking. The students learn a great deal by practicing and explaining their idea or knowledge to others. Peer tutoring method is chosen because there are several advantages. According to Topping and Hill (2012),, The advantages of the peer tutoring such as; (1) students are taught to be independent and have a high sense of friendship (2) The students get easier and more flexible in conveying the problems to their friends so that the student are motivated to learn the materials 
well, (3) to change the students who are less active become active because they are not ashamed to ask questions and express opinions free, (4)Both the tutors and member will get benefit, for the tutor, they will get experience, while the member will be more creative in receiving Lessons (5) By peer tutoring method, The students can get new knowledge and practice essential skills through sharing personal, awareness of individual and social, and focused group learning. (6) Peer tutoring can invite the students to learn actively and teacher is being a guide. (7) Peer tutoring can make the students attentive, listener active, and can provide positive feedback. By these advantages, the peer tutoring method has a role to play to get the better achievement.

Here, the researcher chooses Junior high Sunan Santri Babat as the subject of research. Because this school is located far from central city around $30 \mathrm{~km}$ from Lamongan city, and this school is a private school which is in the location of Islamic boarding school, so the researcher thinks that this school is appropriate to conduct the research. In Junior high school Sunan Santri Babat.

There are a lot of researchers conducted the research about peer tutoring but this research had differences with the previous researches. The difference of this research from the previous researcher was laid on the respondents of the research. Firstly, the respondents of the previous researches were the eight year students of SMPN 3 Sugio Lamongan, while the respondents of this study are VIII grade students of Junior High School Sunan Santri Babat Lamongan. Secondly, previous study used experimental study to compare between peer tutoring and students' levels of interest in writing, while this research compared between peer tutoring and teacher tutoring in speaking. Thirdly, previous study had the differences in choosing the object and the subject applied. The previous study conducted in SMPN 3 Sugio Lamongan to teach writing with different levels of interest, while the present research was to teach the students' speaking at Junior High School Sunan Santri Babat Lamongan. Based on the conclusions above, it was found that peer tutoring was appropriate to can be a consideration that peer tutoring strategy can improve students' competence in speaking. Those also gives 
contribution in the steps applied in teaching using peer tutoring to be adapted in this current study.

The research problem is to find out the different mean score between the students taught by peer tutoring and those by conventional teaching strategies on speaking class. The aim of this research is to know the different mean score between the students taught by peer tutoring and those by conventional teaching strategies on speaking class

According to Topping and Hill (2012), "peer tutoring is people from similar social groupings who are not professional teachers helping each other to learn and learning themselves by teaching". Richard (2009:19) suggested that "the mastery of speaking skill in English is a priority for many second and foreign language learners". As we know that speaking has an important role in human interaction and communication. Then, according to Brown and Yule in Richard (2009:24) "there are three function of speaking: talks as interaction, talk as transaction, and talk as performance".

Talks as interaction refer to the conversation that we do every day. It is a communication done spontaneous by two or more person. This is about the way of someone's when try to convey ideas to other people. Therefore, speaking skill is needed to communicate to other person. The main in this function is social relationship. It means that communicate as a crucial part in someone's interaction to build a relationship with other people. The focus is more on the speakers and how they wish to present themselves to each other than on the massage.

In talk as interaction, the focus in more on the massage that convey and making other people understand what we want to convey, by clearly and accurately (Husnawati, 2017:12). "The speaker produces some words that have certain purpose". The goal is to receive and to send the information between speaker and listener (Lestari, 2018:11). In talk as performance, speaking activities is focus more on monolog (Husnawati, 2017:13). In addition, talk as performance refers to people who work as the public speakers, such as teacher, lecturer, and motivator. 


\section{METHODS}

In this study, the researcher used experiment research design. The purpose of this research was to find out the responds of students about peer tutoring in speaking and to find out the differences of the mean score on students' using peer tutoring and teacher tutoring.

In this research there were 2 variables, dependent and independent variable. The dependent variable was speaking achievement and the independent variable was teaching strategies (peer tutoring and teacher tutoring). The subjects of the research were the second grade students of junior high school Sunan Santri Babat Lamongan. The sample consisted of 20 students of VIII B as the experimental class and 20 students of VIII A as the control class.

The procedure of the research was consisted of pre-test and post-test. The Pre-Test was used to measure the ability of students, then, the subjects of the research get the treatment for three meetings, the treatment was divided by two groups, one group was using peer tutoring and one other was conventional class. after that, a post-test was conducted to get the research data. Finally, the researcher used T-test to know the result of post test.

Pre-Test was conducted to A and B class in this research, the pre-test was conducted twice because in this pandemic of covid 19, this school made the rule for students to study in the school only a half or ten students each class to have social distance, so, the pre-test was conducted on $3^{\text {rd }}$ and $4^{\text {th }}$ of August 2020. The test was using introduction. The students introduce themselves one by one, then, the researchers corrected their pronunciation, fluency, structure, and vocabulary. After that the researcher calculates their score. Then, the researcher analyzes the students' speaking score.

\section{The design of research was as follow:}

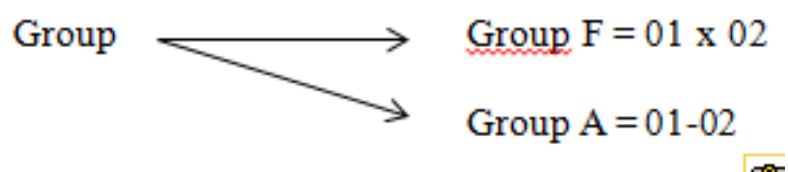


Group F : experimental group

Group A : control group

$01 \quad$ : pre-test

$\mathrm{X} \quad$ : Treatment

$\mathrm{O} 2$ : post-test

\section{FINDING AND DISCUSSION}

The result of the data analysis was taken from pre-test and post-test of both experimental and control group. The result of the data was explained below;

From the pre-test, the researcher conducted test of normality and hegemony to check that both classes were normal and homogeneous.It was the result of Normality Test:

\begin{tabular}{|c|c|c|c|c|c|c|c|}
\hline \multicolumn{8}{|c|}{ Table 1 Tests of Normality } \\
\hline \multirow{2}{*}{ Grup } & & \multicolumn{3}{|c|}{ Kolmogorov-Smirnov ${ }^{a}$} & \multicolumn{3}{|c|}{ Shapiro-Wilk } \\
\hline & & Statistic & $\mathrm{Df}$ & Sig. & Statistic & df & Sig. \\
\hline \multirow{2}{*}{ Pretest } & 1 & .147 & 20 & .099 & .935 & 20 & .066 \\
\hline & 2 & .139 & 20 & .145 & .927 & 20 & .040 \\
\hline
\end{tabular}

a. Lilliefors Significance Correction

Based on Shapiro-wilk test and lilliefors. P Value (sig) liliefors were 0.099 and $0.145>0.05$. So, based on liliefors test in every group was normal. $\mathrm{P}$ value Shapiro-wilk in group 1 was $0.066>0.05$, and group 2 was $0.040>0.05$. So, both of the two group were normal.

A homogeneity test was used to analyze whether the sample variance was homogeneous or not. In this research, it was a formal statistical test for the assumption of homogeneity of variances.

\begin{tabular}{|c|c|c|c|c|c|}
\hline & & $\begin{array}{l}\text { Levene } \\
\text { Statistic }\end{array}$ & df1 & $\mathrm{df} 2$ & Sig. \\
\hline \multirow{4}{*}{ Pretest } & Based on Mean & .295 & 1 & 58 & .589 \\
\hline & Based on Median & .295 & 1 & 58 & .589 \\
\hline & $\begin{array}{l}\text { Based on Median and } \\
\text { with adjusted df }\end{array}$ & .295 & 1 & 58.000 & .589 \\
\hline & $\begin{array}{l}\text { Based on trimmed } \\
\text { mean }\end{array}$ & .302 & 1 & 58 & .585 \\
\hline
\end{tabular}


Based on the table of homogeneity test by levene method, the value of levene was showed in line on mean 0.295 with $\mathrm{P}$ value (sig) $0.589>0.05$. It meant that there was similar variance between the two groups or it could be said homogeny.

After giving the treatment to both experimental and control class, the researcher conducted the post test. The result of post-test was counted by using spss to know the different mean score. The result of T-test as follows:

Table 3. Mean score the experiment and control class

\begin{tabular}{lllcrr}
\hline \multicolumn{6}{c}{ Table 3 Group Statistics } \\
\hline & class & N & Mean & $\begin{array}{c}\text { Std. } \\
\text { Deviation }\end{array}$ & $\begin{array}{c}\text { Std. Error } \\
\text { Mean }\end{array}$ \\
\hline \multirow{2}{*}{ result of study } & a class & 20 & 78.0500 & 2.87411 & .64267 \\
& b class & 20 & 83.7000 & 4.82428 & 1.07874 \\
\hline
\end{tabular}

From the table 3 above, it showed that, the mean score of control class was 78 and the mean score of experimental group was 83, so it could be concluded that control class and experimental class had different mean score.

\begin{tabular}{|c|c|c|c|c|c|c|c|c|c|c|}
\hline \multicolumn{11}{|c|}{ Table 4, Independent Samples Test } \\
\hline & & \multicolumn{2}{|c|}{$\begin{array}{l}\text { Levene's. } \\
\text { Test for } \\
\text { Equality of } \\
\text { Variances }\end{array}$} & \multicolumn{7}{|c|}{ t-test for Equality of Means } \\
\hline & & \multirow[t]{2}{*}{ F } & \multirow[t]{2}{*}{ Sig. } & \multirow[t]{2}{*}{$\mathrm{T}$} & \multirow[t]{2}{*}{ df } & \multirow[t]{2}{*}{$\begin{array}{l}\text { Sig. } \\
(2- \\
\text { tailed) }\end{array}$} & \multirow[t]{2}{*}{$\begin{array}{c}\text { Mean } \\
\text { Differenc } \\
\mathrm{e}\end{array}$} & \multirow{2}{*}{$\begin{array}{c}\text { Std. } \\
\text { Error } \\
\text { Differenc } \\
\mathrm{e}\end{array}$} & \multicolumn{2}{|c|}{$\begin{array}{c}95 \% \text { Confidence } \\
\text { Interval of the } \\
\text { Difference }\end{array}$} \\
\hline & & & & & & & & & Lower & Upper \\
\hline \multirow{2}{*}{$\begin{array}{l}\text { result of } \\
\text { study }\end{array}$} & $\begin{array}{l}\text { Equal } \\
\text { variances } \\
\text { assumed }\end{array}$ & 5.594 & .023 & -4.500 & 38 & .000 & -5.65000 & 1.25567 & -8.19197 & -3.10803 \\
\hline & $\begin{array}{l}\text { Equal } \\
\text { variances not } \\
\text { assumed }\end{array}$ & & & -4.500 & 30.978 & .000 & -5.65000 & 1.25567 & -8.21103 & -3.08897 \\
\hline
\end{tabular}

The table described that the different mean score between equal variances assumed and equal variances not assumed were 0.000 . on sig 2-tailed so it showed 
that the result of this research was significant. It meant, there was a significant different of mean score between experimental class and control class.

From the finding above, there is significant difference on the effect between teaching speaking using Peer Tutoring and Teacher Tutoring. It can be seen from the findings. Generally, Peer Tutoring is more effective than teacher tutoring to teach speaking. Peer tutoring method is proven to be able to improve students' competence in speaking since peer tutoring influences students' imagination to develop their idea in speaking. Peer tutoring is one of the most effective of the cooperative learning methods in speaking.

\section{CONCLUSION}

From the data analysis the results of the research is the mean score peer tutoring method more effective than teacher tutoringin teaching speaking to the VIII grade students of junior high school Sunan Santri Babat Lamongan East Java.

There are some weaknesses in this study, which should be considered by other researchers to conduct better research. The result of the study hopefully become reference for the next researchers.

\section{ACKNOWLEDGMENT}

The first time,the researchers thank to Allah SWT, who always gives his mercies to the researcher. My sincere gratitude is dedicated to the leaders of Lamongan Islamic university (UNISLA) that always supports the researcher, and thanks to PDP program that funded this research. Next, thank is also dedicated to all of the lecturers of English Language Teaching Study Program. Finally, the researcher truly realizes that this thesis needs the constructive criticism and suggestion from the readers to make it better. The researchers hope that it can contribute theoretically to all English learners.

\section{REFERENCES}

Arikunto, S. Prosedur Penelitian Suatu Pendekatan Praktik. Edisi Revisi VI. Jakarta: Rineka Cipta. 2004.

Bahrani, T., \& Soltani, R.. How to teach speaking skill. Journal of education and Practice, 3(2), 25-29. 2012 
Brown, H.D. Teaching by Principles: An Interactive Approach to Language Pedagogy. Fourth Edition. By pearson education Inc. 2015

Calia Robert. What are the steps of the peer tutor cycle? Retrieved from: http://www.eHow.com. 2011

DuPaul, G.J., \& Henningson, P.N. Peer tutoring effects on the classroom performance of children with Attention Deficit Hyperactivity Disorder. School Psychology Review, 22(1), 134-143. 1993.

Ganiyeva, H. Developing Speaking Skills. Архив Научных Публикаций JSPI. 2020

Hamidova, S., \& Ganiyeva, H. Developing Speaking Skills. Архив Hаучных Публикаций JSPI. 2020

Harmer, J. How to Teach English: An introduction to the practice of English Language Teaching. England: Longman. 1998.

Husnawati,Students' Speaking Performance: Some Challenging Factors.pp12- 13, 2017

Jabbarova, A. The Importance of Evaluating Students'speaking Skills. Архив Научных Публикаиий JSPI. 2020

Kuśnierek, A. Developing students' speaking skills through roleplay. World Scientific News, (7), 73-111. (2015

Lestari, S. Exploring the Factors Affecting Students English Speaking Fluency.Pp.11, 2018

Richards, J. Teaching Listening and Speaking from Theory to Practice. The University of Sidney.pp.19 \&24, 2009.

Rao, P. S. The importance of speaking skills in English classrooms. Alford Council of International English \& Literature Journal (ACIELJ), 2(2), 618. 2019

Topping, K\&Hill,S. Peer Tutoring 2012 retrieved from http://www.LTRC.html 